\title{
Foreign Language Teachers Autonomy in Career Development in Colleges and Universities of China-Key Problems and Solutions

\author{
RuiWang
}

School of Foreign Studies, Xi'an University, 710065

Keyword: Foreign language Teacher autonomy; Problems; Solution

\begin{abstract}
In carrying out teaching reform, colleges and universities must pay attention to the development of foreign language teachers in colleges and universities. However, at present, foreign language teachers have a weak sense of career development and their teaching ability needs to be further improved. In order to solve these problems, it is necessary to improve the professional level of teachers and encourage teachers to conduct classroom research and expand the theoretical knowledge, so as to comprehensively improve their overall literacy and ability. This paper mainly discusses the existing problems in the career development of foreign language teachers in colleges and universities and solutions.
\end{abstract}

\section{Introduction}

With the development of society and economy, education in our country is constantly undergoing reforms. Therefore, the teaching faculty is very important. At present, there are still some problems in English teaching in colleges and universities. The strength and quality of teaching staff effectively improved will have a direct impact on the quality of college English curriculum system construction. Therefore, it is necessary to raise the overall awareness of self-development of foreign language teachers in colleges and universities and further improve their overall literacy.

\section{Foreign Language Teachers Autonomy in Career Development in Colleges and Universities of China: Key Problems}

Teachers lack autonomy in Career Development. Teachers autonomy in career development means that teachers should reflect on their own teaching and evaluation, so as to improve classroom teaching efficiency. Some teachers do not have enough seniority and lack of professional knowledge, which leads to the overall development of foreign language teachers is not very satisfactory. What is more, nowadays, the community needs comprehensive talents. For foreign language students, they must understand the business, the economy and various aspects of knowledge. However, with the weak professional quality and ability of foreign language teachers nowadays, foreign language teachers must enrich themselves and improve their professional abilities and teaching abilities. At the same time, teachers should pay attention to their own teaching methods, establish a clear teaching goal, master the advanced teaching concepts and realize the career development. In this way, teachers can carry out useful instructional design according to students' characteristics, so as to improve students' thinking ability and innovative ability. Foreign language teachers in colleges and universities do not conduct professional independent development according to the actual requirements, regard their professional development as part of the development of the side and do not conduct comprehensive and subjective development. Therefore, many teachers in colleges and universities will not take the initiative to carry out independent professional development.

Teaching Ability of Foreign Language Teachers Is Not Good Enough. Due to the increasing number of enrollment in colleges and universities, more and more specialized classes have been set up, which results in increasing pressure on the work of university teachers and the task of teaching is getting heavier and heavier. Besides, many foreign language teachers in colleges and universities have weak awareness in the teaching and research and lack of awareness for their own career planning. Therefore, the teacher's professional research work is difficult to orderly start and their 
own professionalism can not be improved. For foreign language teachers in colleges and universities, the main research topic is to explore and analyze their own majors and teaching methods so as to enhance their own awareness and their professional abilities. As a qualified foreign language teacher, they must have an in-depth understanding of teaching methods. However, many university teachers now lack both a good environment and enough energy to study. To this end, schools must attach importance to the independent professional development of foreign language teachers and give up the traditional way of thinking. Moreover, foreign language teachers in colleges and universities should pay attention to their own professional development, find out the problems existing in teaching in time and acquire certain teaching rules so as to create new teaching ideas and teaching modes and improve teaching efficiency in an all-round way.

Lack of Good Teaching Environment. The teaching environment in most colleges and universities is to use the form of large classes for teaching, then the teaching tasks faced by foreign language teachers will become very arduous. At the same time, it also limits the teacher's own professional development and affects the teacher's career planning and learning enthusiasm. After a while, the status of the teacher will get worse. If the teacher has been in such a state, it will directly affect the quality of teaching. Moreover, many foreign language teachers do not have a professional educational theory and do not have the chance to learn. In the academic field, many teachers simply do not know their own professional aspects, nor do they determine the direction and objectives of their future development and they usually do research for their own job titles. However, there are still many problems in the system for the examination of teachers' titles. Many aspects only require teachers to complete a large number of scientific research tasks and reports, and do not pay particular attention to the quality. Therefore, in face of their future career development, foreign language teachers in colleges and universities will tend to their own professional scientific research, thus neglect their own teaching tasks, which seriously affects the quality of teaching in the classroom.

In foreign language professional research, it is very difficult to publish the scientific research, especially the more important English articles. Moreover, schools only paid attention to the final grade and did not pay attention to the process when they published these key articles. Therefore, the awards were merely superficial work, which thoughts and psychology have seriously affected the teaching of scientific research. It can be seen that schools are not very concerned about the scientific research work of teachers and the support is not enough, which is obviously contrary to the aim of the school. Besides, there is no comprehensive index and the system of assessment for foreign language teachers in the school's rules and regulations. Therefore, there is a deviation in the perception of foreign language teachers in this respect. To this end, schools must increase their support, mobilize teachers' motivation to learn, improve teachers' environment for scientific research and learning and equip better teaching facilities and infrastructure. And to a certain extent, schools should try to create more learning opportunities for teachers and help teachers to conduct more in-depth study. Therefore, the school can apply for and support teachers' scientific research work starting from the school management system and development strategy, thereby enhance the overall ability of teachers and improve the quality of foreign language teaching.

\section{Solutions to the problems of Foreign Language Teachers Autonomy in Career Development in Colleges and Universities of China}

Strengthen Professional Awareness of Self-development. The key to the self-development of teachers lies in the teachers themselves. If teachers want more development, they must attach importance to self-awareness, take the initiative to study and research and solve the problems, so as to improve their professional ability, scientific research ability, creativity and thinking ability. When foreign language teachers cultivate their own sense of autonomy, they can change their position as much as possible, learn to find problems in teaching and then make targeted solutions. In this way, they can effectively overcome the difficulties encountered in the teaching process. For teaching, teachers should integrate self-awareness into their own teaching process and combine these good ideas and teaching together. And then choose appropriate teaching methods according to students' 
learning status and interests and characteristics to help students improve their overall ability and carry out multi-directional development. In the field of professional research and analysis, foreign language teachers mainly need to focus on their own professional to improve their professional ability and comprehensive literacy and apply these research findings to their own educational philosophy to conduct relevant teaching more effectively.

Due to the wide range of foreign language learning, teachers must combine the new concepts and humanities teaching to teach for some comprehensive knowledge, which can better improve students' ability to innovate and comprehensive. Therefore, as a qualified teacher, they must introduce advanced humanities concepts and science and technology for independent innovation. In this way, teachers can better guide their students to establish correct learning concepts and directions. Therefore, foreign language teachers must take the initiative to learn the relevant knowledge and content, and continue to exercise their own comprehensive ability to solve the difficulties, which can let them keep up with the pace of the times and make their professional development more effective. At the same time, foreign language teachers need to establish a clear teaching goal and confirm their future direction of development from the teaching process based on their own situation.

Encourage College Teachers to Carry out Classroom Research. Reflective teaching is to assess and reflect the advantages and disadvantages of teaching. Therefore, foreign language teachers must be a positive attitude and analyse objectively in self-reflection. First of all, teachers must pay attention to the organizational form of foreign language professionals, reflect on the process of professional upgrading, predict the professional future development situation and then re-conduct scientific and rational planning. Second, foreign language teachers should pay attention to their own behavior of reflection and must pay attention to their own teaching practices and methods. In this way, teachers can really understand their own state and location of the classroom teaching. Then teachers can improve their teaching methods through the reflection of teaching process. Moreover, it is necessary to continuously update their own teaching knowledge and concepts to create a better learning environment for students, which can also effectively enhance students' enthusiasm and interest in learning so as to cultivate students' self-awareness and students' independent thinking skills.

Improve the Individual Theory of Foreign Language Teachers in Colleges and Universities. Theoretical knowledge is the foundation, which mainly affects the development and research of foreign language teachers. Therefore, every qualified teacher will constantly improve his or her own theoretical knowledge, learn more knowledge and establish a new knowledge system so as to improve his or her overall literacy. Teaching English is not only limited to this subject, but also need to apply to other disciplines related to knowledge. In addition to learn some English knowledge, teachers also need to pay attention to learn some other basic knowledge. For example, the differences between Chinese and Western cultures, humanities knowledge and spirit are all important factors in improving the quality of English teaching. Therefore, teachers must pay attention to a wide range of knowledge reserves. Only learning more knowledge can teachers better develop their own knowledge base in the process of teaching and learning so as to realize their own professional development.

Improve the Professional Development Environment for College Teachers. For independent professional development of foreign language teachers, environmental infection and influence are also important in addition to personal awareness. School is a sacred place of education, which is closely related to the development of teachers' specialty. Therefore, in order to improve the professional environment for university teachers, school must pay attention to the following aspects. First of all, school must include the development of teachers in the development of school programs, vigorously support the professional development of teachers and formulate a scientific and reasonable reward and punishment system so as to enhance the enthusiasm of teachers and help teachers to carry out relevant professional research more effectively. Second, it is necessary to give certain protection policies to pay attention to the educational status of foreign language disciplines. Besides, schools regularly carry out teacher training activities and give them a lot of encouragement. 
In addition, it is necessary to formulate a scientific and reasonable evaluation system of teachers' professional standards and support teachers in their balanced development while carrying out research and teaching work. School also should focus on the cooperation between teachers and teachers, so that teachers can help each other and better promote their own professional development. Moreover, the professional development of teachers also needs the support of relevant departments. Therefore, it is necessary to coordinate the teaching environment of teachers and establish a harmonious co-existence environment so as to effectively carry out independent professional development.

\section{Conclusion}

To sum up, teachers are also very important to education other than students. Therefore, the foreign language teachers autonomy in career development in colleges and universities is very important. It can effectively improve the professional ability and comprehensive literacy of foreign language teachers, help teachers to establish new teaching concepts, learn more educational theories, establish a sound knowledge system and obtain more effective teaching methods.

\section{Reference}

[1] Z. Q. Wang and S. P. Wang. Study on the Professional Development Consciousness of College Young Foreign Language Teachers [J]. Journal of Jiamusi Vocational College, 2017, (09): 244-245.

[2] J. X. Ren. Problems and Solutions of Self-reliant Development of Foreign Language Teachers in Colleges and Universities [J]. Journal of Henan Institute of Science and Technology, 2016, (06): $37-40$.

[3] X. H. Jiang. Study on Self-development of Foreign Language Teachers in Higher Education Institutions under Teacher Professional Development [J]. Heilongjiang Higher Education Research, 2013, (01): 95-98.

[4] H. Wu. Study on the Status Quo and Countermeasures of Independent Professional Development of Young Foreign Language Teachers in Colleges and Universities [J]. Chinese Foreign Languages, 2011, (04): 71-75. 